\title{
Hera and the Return of Charaxos
}

\author{
Deborah Boedeker
}

The longest of the new Sappho fragments, the 'Brothers Poem' or, as I prefer to call it, the 'Charaxos Poem', engages its twenty-first century audience with a number of questions, to which contributors to this volume propose a variety of solutions. ${ }^{1}$ Who is the speaker's silent interlocutor? Are Charaxos and Larichos historical brothers of Sappho, or 'types' in a Lesbian poetic or ritual tradition? How does the first-person speaker relate to each of these male figures, and to the interlocutor? What is meant by the wish at the end of the poem that Larichos 'lift his head' and 'become a man?'

\section{Introduction: Hera in the Charaxos Poem}

Even with so many matters still under lively debate, readers can agree that the song reflects a world of seafaring and trade, ${ }^{2}$ as seen in its focus on a safe return

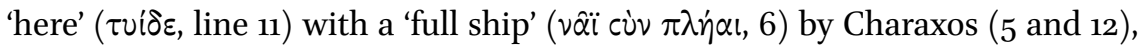
known to the biographical tradition as a trader and a brother of Sappho.

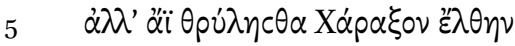

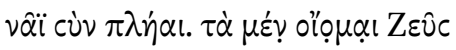

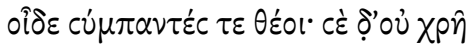

$\tau \alpha \hat{\tau} \tau \alpha$ vónc $\theta \alpha \mathrm{l}$,

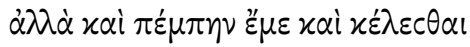

10

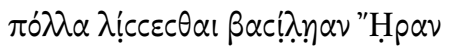

1 It is a pleasure to thank Anton Bierl and André Lardinois, organizers and editors par excellence. For discussion and feedback I am grateful to them and to other contributors to this volume, to fellow-participants at a symposium on the new fragments held at Bard College in October 2014, and to a gracious audience at the University of Leiden. None of the above, needless to say, is responsible for this paper's shortcomings.

2 On archaic trade as related to figures such as Charaxos, see Raaflaub's contribution to this volume.

(C) DEBORAH BOEDEKER, 2016 | DOI: 10.1163/9789004314832_010

This is an open access chapter distributed under the terms of the Creative Commons Attribution-

Noncommercial 3.o Unported (CC-BY-NC 3.o) License. 


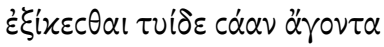
$\nu \hat{\alpha} \alpha \mathrm{X} \alpha \dot{\rho} \alpha \xi \circ \nu$

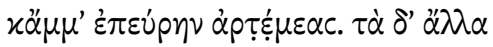

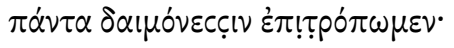

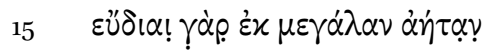

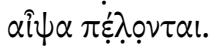

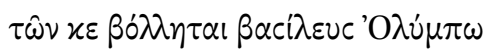

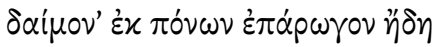

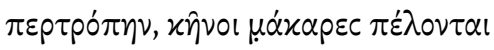
xai $\pi 0 \lambda \dot{0} 0 \lambda \beta \circ 0^{\circ}$

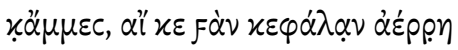

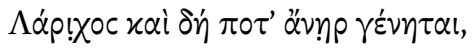

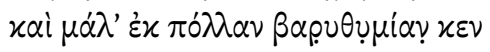
$\alpha i \psi \alpha \lambda \dot{\theta} \theta \varepsilon ı \varepsilon \varepsilon . \otimes$

5 you keep chattering about Charaxos coming with his ship full. Zeus knows these things, I believe, and all the gods.

You should not think about this,

but instead send me, urge me to pray profusely to Queen Hera that Charaxos return here guiding his ship safe and find us unharmed. Everything else let us turn over to the higher powers, for from great gales clear skies quickly emerge.

Whomsoever the King of Olympus wishes a helper daimon to turn away now from troubles, they become blessed and very fortunate.

And we too-if ever Larichos should raise his head and become a man- 
we too would quickly be freed 24

from the many cares weighing down our hearts.

Hera's help is relevant not just to Charaxos but also to those awaiting his return. The goddess should be asked to bring the seafarer back with a safe ship ( $c \alpha \alpha \alpha \nu . . . \nu \hat{\alpha} \alpha$, lines 11-12), and also to let him find 'us' $\alpha \rho \tau \xi \tilde{\mu} \mu \varepsilon \alpha c$ 'safe and sound' (line 13). ${ }^{3}$ René Nünlist shrewdly comments that this prayer suggests trouble at home, not just at sea, noting that Odyssey 13.42-43 presents a close parallel to the (imagined or implicit) situation of Charaxos returning to his loved ones. In that passage, Odysseus bids farewell to his Phaeacian host Alkinoos with the wish, 'May I find my blameless wife at home when I return, with my dear

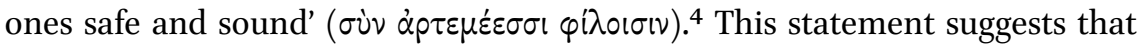
Odysseus suspects or fears something like the critical situation (well-known to the epic audience) that threatens Penelope, Telemachus, and his loyal servants on Ithaca.

This rare poetic word, of unknown etymology, is used only twice more in archaic epic, as many commentators on this passage have pointed out, both times from the perspective of those who perceive a dear one unexpectedly returning unharmed from what had threatened to be grave danger. When Aeneas returns to the battlefield after being wounded by Diomedes and then secretly healed in Apollo's sanctuary, his comrades were amazed and overjoyed

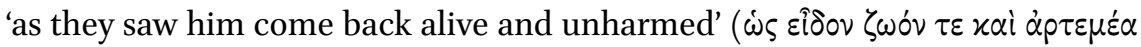

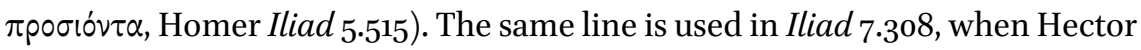
returns safe from his (supposedly) mortal combat with Ajax.

In the Charaxos Poem, at line 9 the focalization subtly shifts from those who await the return of Charaxos to the voyager's own perspective, as he (it is to be

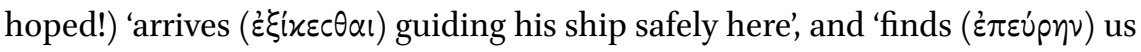
safe and sound' (lines 11-13). Thus, Hera is asked to bring about relief and safety for both sides, the voyager and those awaiting him.

The speaker's concerns are apparent. But why should Hera be the god to beseech in this situation? Her prominence in the song, although limited to a few lines, is striking: in standard works on Greek religion she has little or nothing to do with seafaring and trade, ${ }^{5}$ and she is mentioned very rarely in

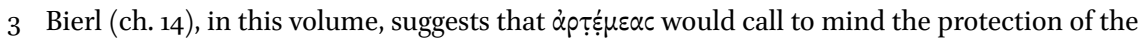
chaste Artemis; I believe that the association, while possible, would not be especially resonant for Sappho's audience.

4 Nünlist (2014). Similarly, Ferrari (2014) 3-4; Morgan, in this volume. Nünlist also lists, without

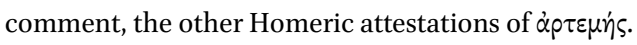

5 No such connection is mentioned, for example, in the sections on Hera in Burkert (1985) 131- 
the corpus of Sappho. This contribution examines the goddess's relevance in the new song, in light of a larger religious-historical context.

\section{Sappho's Hera}

Although Hera is frequently associated with marriage in Greek cults and iconography, ${ }^{6}$ she appears neither in Sappho's epithalamia nor in her narrative of the wedding of Hector and Andromache (fr. 44). Prior to the publication of the Green Collection papyri, in fact, the only secure attestation of Hera's name was at fr. 17.2. ${ }^{7}$ In that fragment, which has now been expanded by the new papyri, Hera is also associated with the hope of finding a way home by sea.

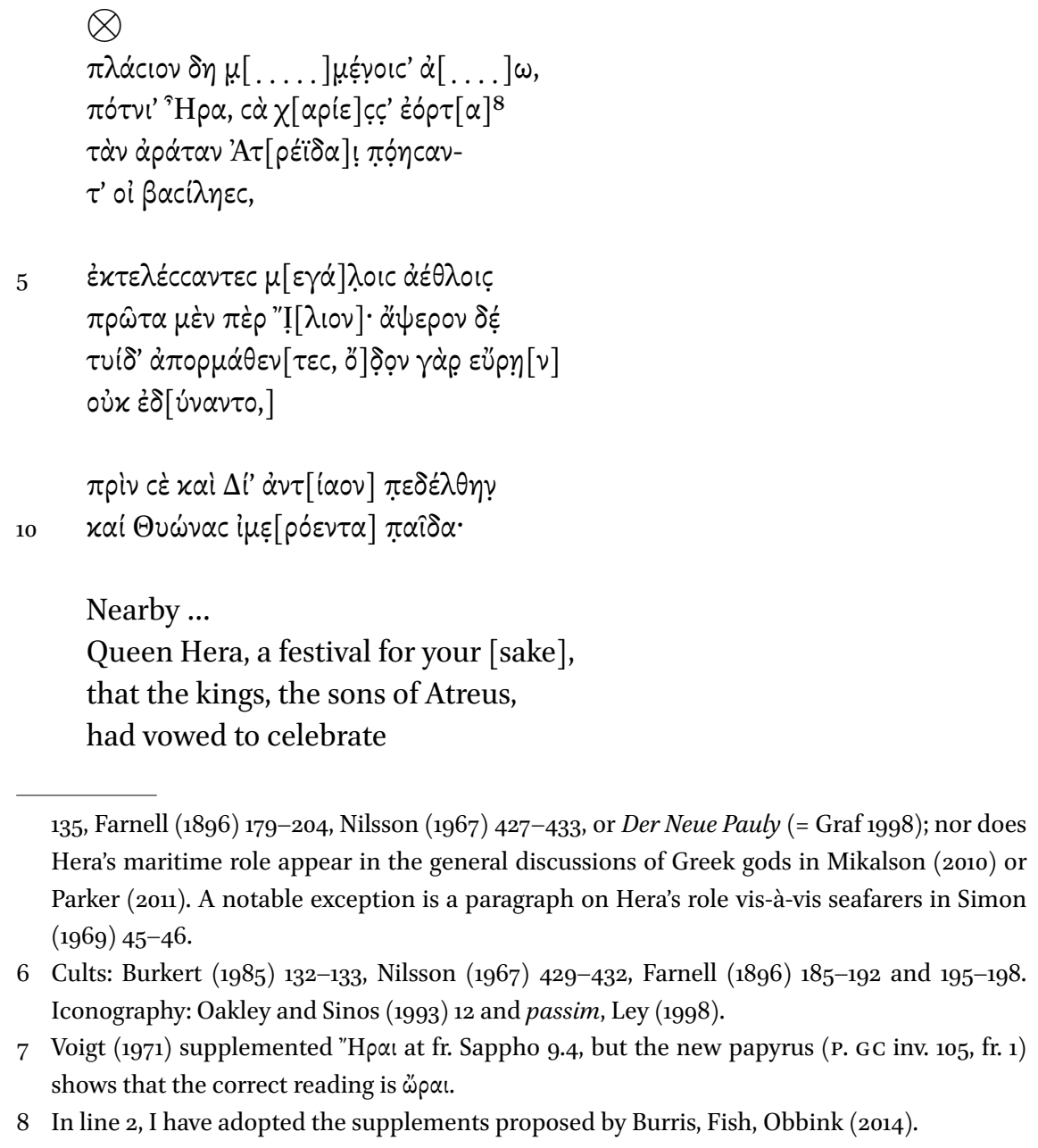

135, Farnell (1896) 179-204, Nilsson (1967) 427-433, or Der Neue Pauly (= Graf 1998); nor does Hera's maritime role appear in the general discussions of Greek gods in Mikalson (2010) or Parker (2011). A notable exception is a paragraph on Hera's role vis-à-vis seafarers in Simon (1969) 45-46.

6 Cults: Burkert (1985) 132-133, Nilsson (1967) 429-432, Farnell (1896) 185-192 and 195-198. Iconography: Oakley and Sinos (1993) 12 and passim, Ley (1998).

7 Voigt (1971) supplemented "H $\mathrm{p} \alpha \mathrm{l}$ at fr. Sappho 9.4, but the new papyrus (P. GC inv. 105, fr. 1) shows that the correct reading is $\omega$ pal.

8 In line 2, I have adopted the supplements proposed by Burris, Fish, Obbink (2014). 
5 when they had completed great labors, first around Troy and later stopping here, for they could not find the seaway

before seeking you and Zeus, god of 10 suppliants, and Thyone's alluring son. SAPPHO fr. 17.1-10 (trans. RAYOR, modified)

As scholars have long noted, ${ }^{9}$ the narrative in fr. 17.3-10 recalls an episode in the Odyssey, 3.168-175, where Nestor (who does not appear in Sappho's version) tells Telemachus about a critical stop he made at Lesbos in the voyage home from Troy.

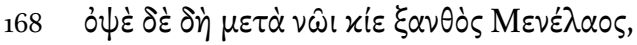

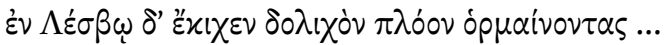

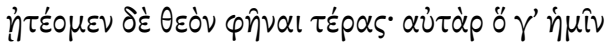

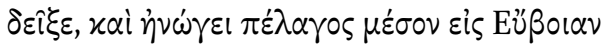

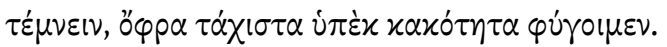

but fair-haired Menelaus came late behind us, and caught up to us in Lesbos, as we pondered the long voyage ...

173 We asked the god to show us a portent, and he revealed one to us; he told us to cut through the midst of the sea to Euboea, so that we most quickly could escape from distress.

The god who sent the portent on Lesbos is not named here, but the masculine " $\gamma$ ', ('he', line 173) clearly excludes Hera. Denys Page assumes it was Zeus, ${ }^{10}$ but Nestor goes on to tell Telemachus that when he reached Geraistos (at the southern tip of Euboea), he sacrificed to Poseidon (Od. 3.177-179) - the Homeric god most closely associated with seafaring. ${ }^{11}$ In the Odyssey passage as well as Sappho fr. 17, then, Lesbos figures as a pivotal place both for the Atreid

9 E.g. Page (1955) 59-6o, Lidov (2004) 401-402, and the contributions of Lidov (chs. 3 and 19), Caciagli, and Nagy, in this volume.

$10 \quad$ Page (1955) 59-6o.

11 For a detailed interpretation of the Odyssey passage, including the sacrifice at Geraistos and the pivotal role of Lesbos for the Homeric Nostoi, see Nagy's contribution to this volume. 
Menelaus and for Nestor-the quintessential 'home-bringer' in the etymology of his name as well as in his epic role ${ }^{12}$ - as they contemplate how to cross the Aegean on their way home from Troy. ${ }^{13}$

An important new addition to the text of fr. 17.2 provides a Lesbian cultic perspective on the request for help: a festival $(\dot{c} \rho \tilde{\rho} \tau[\alpha])$ was celebrated for Hera.

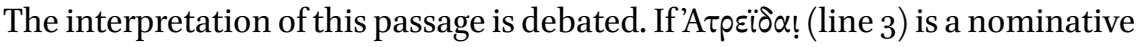

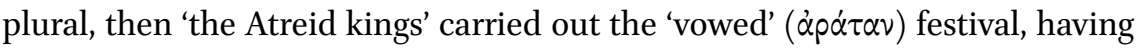
set off for Lesbos after their toils at Troy, to seek help in finding the way home. ${ }^{14}$ But if'A $\tau p \varepsilon i ̈ \delta \alpha !$ is a dative singular, then 'the kings' carried out the festival vowed for an Atreid, presumably Menelaus. ${ }^{15}$ (I find the nominative plural more likely, although this question has little bearing on my general point about Hera's importance to seafarers.) If Milne's restoration ["H] $\rho^{\prime}$ in line 20 is correct, ${ }^{16}$ Hera's name appears again at the end of the song, following a lacunose passage (lines 11-16 or further) on the songs and dances that 'we' too perform 'now' (1112), as in olden times, in honor of the goddess.

As presciently argued before the new papyri made it clear, ${ }^{17}$ this festival is presented as the locus and the focus of fr. 17. Very plausibly, the same temenos is the speaker's desired destination in the Charaxos Poem: send me to ask Queen Hera to bring Charaxos home safe. This song may have been intended for performance at such a festival, as Bierl, Lidov, and Nagy argue in this volume. Lidov (ch. 3, this volume,) further suggests that an annual 'multi-part festival' celebrating the homecoming of sea traders, together with marriage ceremonies, was celebrated annually at Hera's temenos, and that this festival served as the performance locus for the songs in Sappho's first book, including the Charaxos Poem. In its content, however, as I understand it, the new song presents a critical situation in which the goddess' help should be sought through immediate

\footnotetext{
12 See Frame (1978) 81-115; Frame (2013) 28-29, 182-191, and passim.

13 At Odyssey 4.81-85, Menelaus lists for Telemachus a number of places he visited on his eight-year-long journey home from Troy. Lesbos is not among them, but since the hero's catalogue begins only with Cyprus, this does not necessarily preclude a stop on Lesbos earlier in his voyage.

14 So West (2014) 4. Neri (2014) 15 less persuasively argues that the lines must mean 'your joyful festival) which the Atreids, the kings, hoped (i.e. desired) for themselves', with the only meaning that äpa $\mu \alpha$ has in Sappho. See Obbink (ch. 1, this volume) for a concise review of editorial and interpretive suggestions.

15 For this interpretation see Burris, Fish, Obbink (2014) 19-20 as well as Obbink (ch. 2) and Lidov (ch. 19) in this volume.

16 West (2014) 5 now tends to accept this reading.

17 Calame (2009) 3-7 and Wilson (1996) 181-182. See now Obbink, ch. 1, this volume.
} 
prayers, rather than waiting for an annual festival. Familiarity with the festival, however, and especially of Hera's role as helper of seafarers, would greatly enrich the audience's understanding of the urgent request that the speaker makes to her interlocutor.

Hera's name may also be attested in the new additions to Sappho fr. 5. The song begins with an address to the Nereids, asking them to let the speaker's

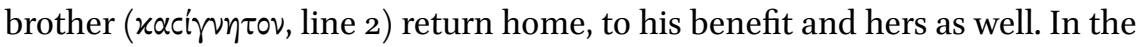
sadly lacunose final strophe, Kypris is mentioned, and possibly Hera too, if a supplement proposed by Burris, Fish, and Obbink (2014) is correct: ${ }^{18}$

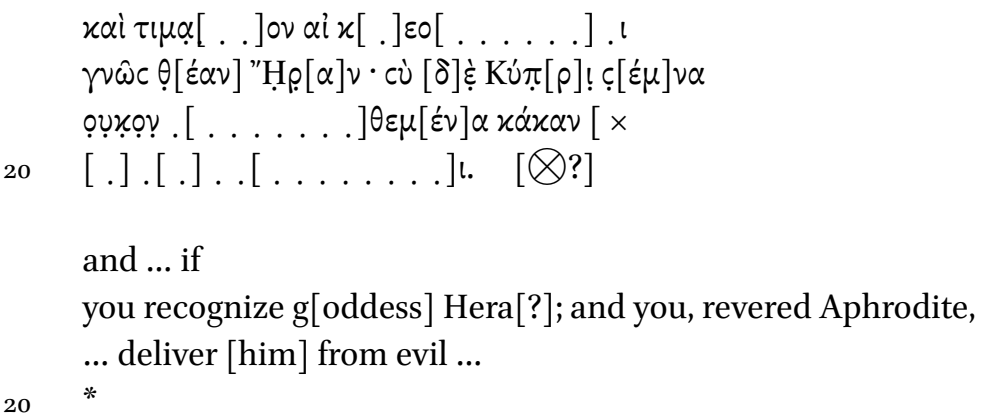

trans. RAYOR, except for line 18

Even if this supplement is correct, Hera's role in the song is unclear-but at least her name would be mentioned, as it is always is in the extant fragments of Sappho, in a song concerned with a troubled return from sea.

The brother is not named in fr. $5,^{19}$ and conversely, in the Charaxos Poem, 'Charaxos' is not called a brother; nonetheless it seems ever more likely that these two fragments from the first book of Sappho are part of a cycle of songs about the errant seafaring brother-be he biographical or fictional. ${ }^{20}$ In both the Charaxos and the Nereids songs, the female speaker voices (or wishes to voice) a prayer that this figure will return safely as a boon to his family

18 Burris, Fish, Obbink (2014) 26. See now Obbink's edition (ch. 1) in this volume, which records also the alternative readings proposed by West (2014) 6-7 and Ferrari (2014) 6 . On the name Kypris in Sappho, see Schlesier's contribution to this volume.

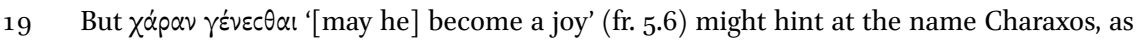
suggested by Burris, Fish, Obbink (2014) 24, citing Posidippus Epigr. 17 Gow-Page (= 122

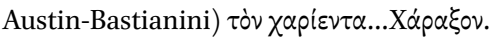

20 As discussed in the contributions to this volume by Obbink (esp. ch. 2), Lidov (ch. 3), Lardinois, Nagy, and Stehle; for different perspectives on the question of biography vs. fictionality, see also the contributions to this volume by Peponi and Raaflaub. 
members; significantly, and in keeping with very general norms of Greek prayer, the deities this speaker addresses are overwhelmingly female. ${ }^{21}$ Hera is the most prominent of the three gods sought by the homecoming Atreids in fr. 17; the deities mentioned in fr. 5 are the Nereids, Kypris, and possibly Hera; and of course Hera is the god to beseech in the new Charaxos Song.

In Homeric epic, Hera occasionally operates in this sphere as well, protecting or harming heroes at sea. ${ }^{22}$ Zeus in Iliad 15 reminds his wife how he punished her-suspended from a golden chain, her feet weighed down with anvilsbecause she had driven his beloved son Heracles off-course: 'prevailing upon the storm-winds ( $\theta v \varepsilon \dot{\lambda} \lambda \alpha \varsigma$ ), with Boreas' help you malevolently ( $\propto \alpha \varkappa \dot{\alpha} \mu \eta \tau i o ́ \omega \sigma \alpha)$ drove him over the unploughed sea to Kos.' ${ }^{23}$ In Proclus' summary of the Cypria, Hera sends a storm $(\chi \varepsilon \mu \omega \hat{\omega} \nu \alpha)$ against another enemy, Paris, as he sails off with Helen, thus preventing the Trojan prince's safe and straightforward homecoming with his cargo. ${ }^{24}$

Hera's role vis-à-vis seafarers in the Odyssey is more positive. As Circe instructs Odysseus on how to get home, she names Hera as protector of the Argonauts: because Jason was dear to her, she helped the Argo sail safely through the Clashing Rocks. ${ }^{25}$ In Odyssey 4.512-513, Menelaus tells Telemachus that the same goddess saved $\left(\sigma \alpha \dot{\alpha} \omega \sigma^{\prime}\right)$ Agamemnon on his way home from Troy, whereas Locrian Ajax was destroyed. ${ }^{26}$ As Nagy argues in this volume, the Agamemnon passage relates closely to Sappho fr. 17, where the Atreids (or an Atreid) are connected with a festival of Hera on Lesbos and, subsequently, a homeward voyage from Troy.

21 On the role of gender in mortal/god relations in the Charaxos poems, see especially the contributions to this volume by Stehle, Kurke, Lardinois, and Bierl (ch. 14).

22 Lidov (2004) provides a comprehensive discussion of this pattern; see also Nagy's contribution to this volume.

23 Iliad 15.23-24. On the dangers faced by Heracles on Kos at Iliad 14.250-261, see Janko (1992) 191-192; Krieter-Spiro (2015) ad Iliad 14.249-261 and 254.

24 Cypria fr. 14 Bernabé; Paris and Helen were subsequently blown to Sidon, which Paris conquered. Herodotus 2.116-117, however, says that in the Cypria the pair sailed smoothly straight to Troy, in contrast to the Homeric tradition of their wanderings; Sappho fr. 16 includes no hint that this voyage did not proceed uneventfully. See Lidov (2004) 403.

25 Odyssey 12.68-72, discussed in O'Brien (1993) 157-158 and Simon (1969) 45. Hera's role in the Argonaut saga is most elaborately developed, of course, in Apollonius' Argonautica. Note that according to Pausanias 7.4.4, the Argonauts first brought the image of Hera to Samos.

26 O'Brien (1993) $15^{8}$ notes this passage in light of Hera's protection of other Achaean heroes. 


\section{The 'Lesbian Triad' Sanctuary}

A question that has attracted considerable interest (and growing consensus) among scholars is the location and nature of the sanctuary where that festival was celebrated. Sappho fr. 17.9-10 provides a clue, in that Zeus $\dot{\alpha} \nu \tau[\text { i } \alpha \circ \nu]^{27}$ 'of suppliants' and Thyone's son (Dionysus) are invoked along with Hera. ${ }^{28}$ Sappho's contemporary Alcaeus describes in fr. 129 a great pan-Lesbian temenos that features altars of the same three gods, albeit only Zeus $\alpha v \tau i \alpha 0 \varsigma$ receives the same epithet as he does in the Sappho fragment. ${ }^{29}$ The fragment begins:

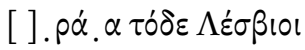

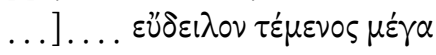

$$
\begin{aligned}
& \xi \hat{v} v 0 v x \alpha \dot{\alpha}[\tau \varepsilon] \sigma \sigma \alpha \nu \text { ह่v } \delta \dot{\varepsilon} \beta \omega \dot{\mu} \mu 01 \zeta \\
& \theta \alpha \nu \alpha \dot{\tau} \tau \omega \nu \mu \alpha x \alpha \dot{\rho} \rho \omega \nu \text { हैं } \eta x \alpha \nu
\end{aligned}
$$

$5 \quad x \dot{\alpha} \pi \omega \nu \dot{\mu} \mu \alpha \sigma \sigma \alpha \nu \dot{\alpha} \nu \tau i \alpha \sigma \nu \Delta \dot{\alpha} \alpha$

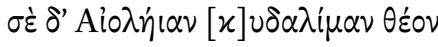

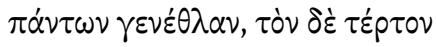

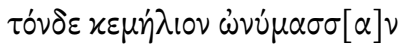

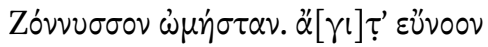

10

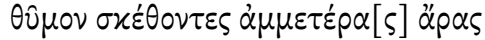

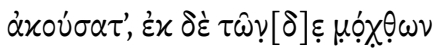

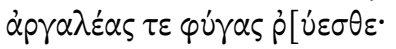

the Lesbians established this great conspicuous sanctuary to be held in common, and put in it altars of blessed immortals,

5 and they named Zeus 'god of suppliants' and you, Aeolian, glorious goddess,

\footnotetext{
27 The supplement is supported by $\alpha v \tau i \alpha o v \Delta^{\prime} \alpha$ in Alc. fr. 129.5 (discussed below).

28 The inclusion of Dionysus in this sanctuary is noteworthy, since in many instances Hera was famously hostile to him; see Farnell (1896) 1.193 for examples.

29 On Alcaeus fr. 129 see Bierl (2016 forthcoming) 19-23.
} 
'mother of all', and this third they named 'Kemelios', 30

Dionysus eater of raw flesh. Come with

10 gracious spirit, hear our prayers and rescue us from these hardships and from grievous exile ...

The three gods, often called the 'Lesbian trinity' or 'triad', are present in both accounts of the sanctuary, but they are not presented entirely ex aequo. Sappho fr. 17 begins with Hera; she alone is addressed in the second person (line 2), and may even be mentioned twice (at lines 2 and 20). The narrative in the first ten lines focuses on a festival in her honor, and she is most prominent ${ }^{31}$ in the appeal to the three gods for help in finding a way home: not only is Hera mentioned before her fellow immortals, but she even receives another secondperson reference (line 9).

In Alcaeus fr. 129, Zeus is mentioned first - as might be expected for the king of the gods in a context where the speaker demands justice and/or vengeance (cf. e.g. Archilochus fr. 177). Here too, however, only Hera is addressed in the second person (if, as is almost certain, she is to be identified with the 'Aeolian goddess $^{32}$ ), and with a longer set of epithets. ${ }^{33}$

Another Alcaeus song, fr. 130b.16-20, evokes a sanctuary (plausibly taken to be the same temenos as described in fr. $129^{34}$ ) where the speaker was driven in exile ( $\dot{\alpha} \pi \varepsilon \lambda \dot{\eta} \lambda \alpha \mu \alpha / / \varphi \varepsilon \dot{\gamma} \gamma \omega \nu$, lines 8-9):

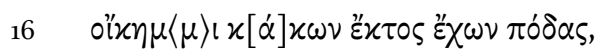

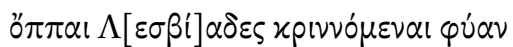

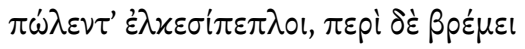

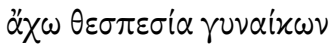

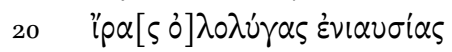

30 On the epithet see Liberman (1999) 1.62, and Bierl's contribution to this volume (ch. 14), with references.

31 Pace Lidov (ch. 3, this volume), who finds that Dionysus has 'pride of place' here.

32 See Caciagli (2010) 234 on Hera as the 'Aeolian goddess'.

33 Dionysus, mentioned third, also enjoys a longer appellation than Zeus (but no direct address).

34 See Liberman (1999) 1.63, with bibliography. 
keeping my feet away from troubles, I live

where Lesbian women, being judged for beauty, come and go in their long robes, and all around resounds a wondrous echo of women, the sacred yearly ololyge

An ancient commentary on the Iliad famously declares that the beauty contests $(\varkappa \alpha \lambda \lambda 1 \sigma \tau \varepsilon \hat{i} \alpha)$ Alcaeus witnessed took place at 'the sanctuary of Hera' ( $\dot{\varepsilon} \nu \tau \hat{\omega} \tau \hat{\eta} \varsigma$

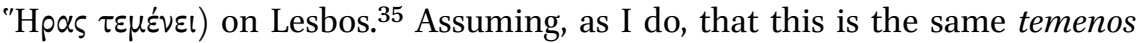
as the one mentioned in Alcaeus fr. 129 and referred to in Sappho fr. 17, the scholion supports the view that this sanctuary was primarily a Heraion, shared with Zeus and Dionysus — or at least that it was best known for a festival of Hera. ${ }^{36}$

This view is corroborated by an anonymous Hellenistic epigram (Anth. Pal. 9.189), in which Lesbian women or girls, led by Sappho herself, are summoned to dance at a 'splendid temenos of Hera':

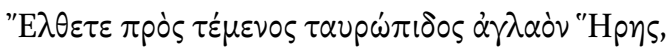

$\Lambda \varepsilon \sigma \beta i \delta \delta \varepsilon, \dot{\alpha} \beta \rho \dot{\alpha} \pi \circ \delta \omega \nu \beta \hat{\eta} \mu \alpha \theta^{\prime} \dot{\varepsilon} \lambda{ }_{1 \sigma \sigma o ́} \mu \varepsilon v \alpha l \cdot$

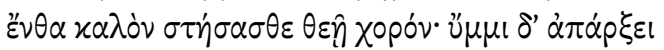

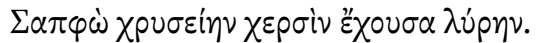

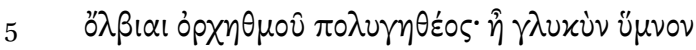

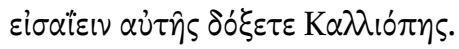

Come to the splendid sanctuary of ox-eyed Hera, girls of Lesbos, whirling the delicate steps of your feet.

Form there a beautiful chorus in honor of the goddess.

Sappho will lead you with the golden lyre in her hands.

Blessed you in the joy of your dance: surely you will

believe you are listening to the sweet song of Calliope herself. trans. FERRARI

Where was this splendid temenos in which the three gods were honored and a grand festival of Hera was held? In 1961 Jerome Quinn argued, based largely on

35 Scholion D A on Iliad 9.129.

36 Robert (196ob) 314 n. 4 suggests this possibility; similarly Neri (2014) 22 n. 72 (citing Alc. fr. 130.15, AP 9.189.1, and the scholion in P. Oxy. 2165 fr. 1 col. $133-39$ ). Bierl, ch. 14 in this volume, argues for the importance of Dionysus in Alcaeus frs. 129 and 130. 


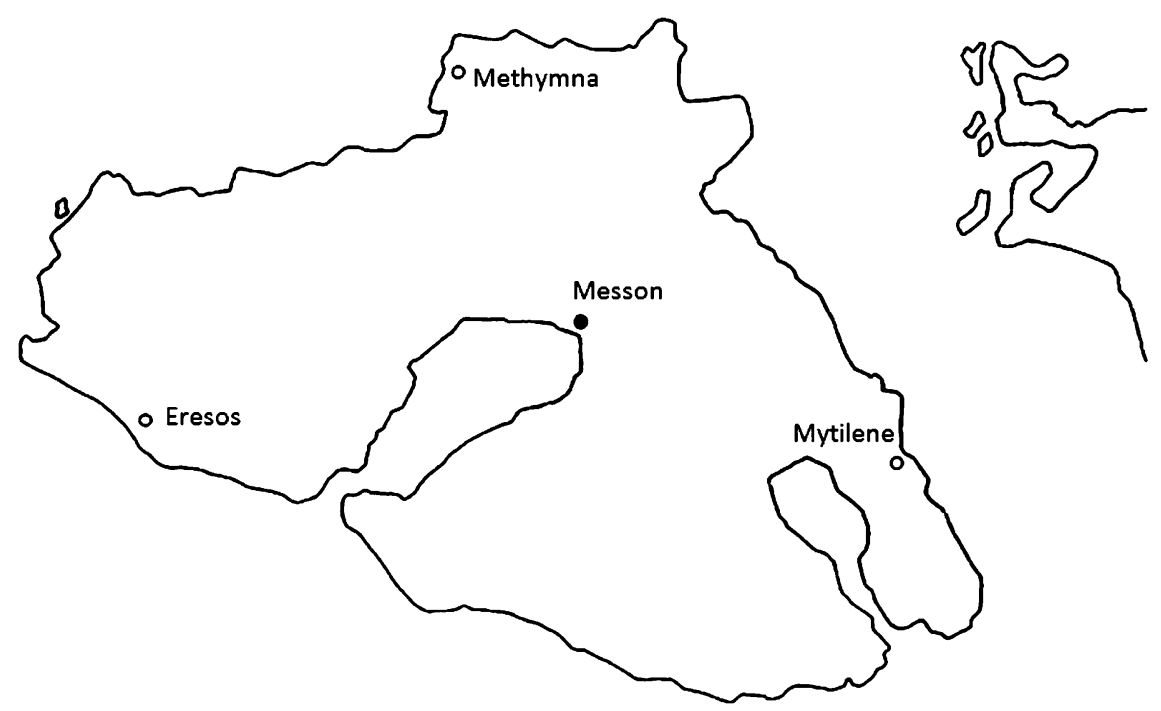

FIGURE 8.1 Map of Lesbos showing the location of ancient Messon

DRAWING BY RENÉ REIJNEN. IMAGE COPYRIGHT (C) RADBOUD UNIVERSITY

topography, that the location of Alcaeus' 'great conspicuous sanctuary' accords well with Cape Phokas [also spelled Fokas] on the south coast of Lesbos. The cape, which lies east of the entrance to the Bay of Kalloni, has remains of a small Hellenistic temple of Dionysus (one member of the 'Lesbian triad'). ${ }^{37}$ The great majority of experts, however, have been persuaded by Louis Robert's argument, first published in 1960 and based primarily on epigraphical data from the second century CE, that Alcaeus' temenos, the conspicuous sanctuary held in common by all Lesbians, was located at Messon (modern Mesa). ${ }^{38} \mathrm{I}$ agree that the evidence favors Messon, but my argument requires only that the site lie near an ancient harbor - and according to a recent survey of the ports of Lesbos, that is true of both these sites. ${ }^{39}$

37 As argued by Quinn (1961), whose conclusions are approved by Campbell (1967) 294 (ad Alc. 129.2) and Picard (1962). On the remains of the temple see Spencer (1995) 17.

38 See Fig. 8.1, this page. For detailed discussion, see the contributions of Bierl (ch. 14), Caciagli, and Nagy in this volume.

39 'Mapping the ancient ports of Lesbos', a project of the Eastern Mediterranean Maritime Archaeology Foundation, reports: 'In 2009, both St. Fokas's port [ancient Vrissa] and a small rock fill close to the ancient sanctuary of Messa in the Mesitziki spot in Kalloni Bay were completely mapped. Furthermore in St. Fokas, apart from the preserved windward mole, the team discovered a second underwater breakwater for the protection of the mole from the east' (http://www.emmaf.org/ accessed May 6, 2014). On Cape Phokas, see also 
As its name would suggest, Messon occupies a central position on Lesbos, near the northeast corner of the Bay of Kalloni. ${ }^{40}$ In his gazetteer of Lesbian archaeological sites, Nigel Spencer notes that the late fourth-century temple which is now visible covers an undated earlier structure, and that some archaic graves and fine-ware pottery have been found near the site. Spencer adds that there could have been an open-air archaic sanctuary. ${ }^{41}$ Few traces remain of the site that would have been known in 600 BCE, the period ascribed to Sappho and Alcaeus, except (as we have seen) traces of an anchorage in the bay nearby.

\section{Hera as Maritime Goddess in the Archaic Mediterranean}

Not only on Lesbos, but in a number of other Mediterranean sites as well, sanctuaries of Hera were located at harbors or capes. ${ }^{42}$ At Perachora, with its small harbor on the Corinthian gulf, there was a temenos dedicated to Hera Akraia. ${ }^{43}$ Humfry Payne, who excavated there in the early 1930s, believed that he had discovered a second sanctuary, a little higher up, to Hera Limenia, ${ }^{44}$ although more recently R.A. Tomlinson has argued that this was just an extension of the Akraia sanctuary. ${ }^{45}$ At any rate, this maritime Hera cult flourished especially in the latter seventh to sixth century, the historical period assigned to Sappho's world. ${ }^{46}$ Finds there include many that indicate its importance to those engaged in wide-ranging trade routes, including Phoenician bronzes of the eighth and seventh centuries, and some 9oo Egyptian or Egyptian-style scarabs. Because the pottery at the site is largely of local provenance, however, Tomlinson declares that the sanctuary was 'primarily of local interest', with the 'international element in the objects found there reflecting the overseas con-

Quinn (1961) 392; on Messon's location near a port, see Caciagli (2010). I regret that I have not been able to see Theodoulou (forthcoming).

40 Robert (196ob) 306-315; see further the detailed assessment of Caciagli (2010).

41 Spencer (1995) 22-23 with bibliography.

42 I refer again to the admirable paragraph in Simon (1969) 45-46.

43 This sanctuary is well known from Euripides, Medea 1378-1380, where the heroine says she will bury the bodies of her children there, to keep them safe from the Corinthians' wrath; on the connection of this cult with a 'reproductive demon' figure, see Johnston (1997).

44 Payne (1940) 110-122.

45 Tomlinson (1992) 322-323.

46 Idem. 
tacts of the Corinthians themselves', but he also maintains that 'dedications were made there by sailors travelling up or down the gulf of Corinth.' ${ }^{47}$

Elsewhere in the Peloponnese, there was a Heraion at Tiryns on the Argolic gulf. In Naukratis, the mixed Greek trading city in Egypt, where according to Strabo, Sappho's brother Charaxos traded wine, ${ }^{48}$ there was a Heraion, established by the Samians. ${ }^{49}$ (Thus if the Charaxos Poem and/or Sappho fr. 5 presume that Charaxos is returning from Egypt, Hera may be relevant both at the beginning and end of his voyage.) A Heraion is attested on Cape Lacinia near Croton in southern Italy, ${ }^{50}$ one at Foce del Sele on the Italian west coast near Poseidonia (see below), and another at Gravisca, the harbor of Tarquinia. At the Samian colony Heraion Teichos on the Propontis, the place-name strongly suggests that there was yet another. ${ }^{51}$ An inscription from Thasos (IG 12 Suppl. 409) mentions a Hera Limenaia, as well. ${ }^{2}$

Most of all, of course, there was the Heraion at Samos, a short distance from the coast. A tale in Herodotus suggests the importance of this sanctuary for local seamen. It tells the story of a Samian merchant ship, captained by a certain Kolaios, that was blown off course when heading for Egypt. According to Herodotus (4.152.2-4),

(2) ... [the sailors] were driven off course by an east wind, and as the blast did not let up, they passed through the Pillars of Heracles and arrived at Tartessus, enjoying divine accompaniment $(\theta \sin \pi \circ \mu \pi \hat{\eta} \chi \rho \varepsilon \dot{\omega} \mu \varepsilon v o l)$. (3) This market was untouched at that time, so that when these men returned home, of all Greeks about whom we have precise information, they got the greatest profit from their cargo - except for the Aeginetan Sostratus, son of Laodamas (no one else can compete with him). (4) The Samians took a tenth of their profits, six talents, and made with it a bronze object in the style of an Argolic mixing bowl, with griffin-heads spaced all around it. They set this up in the Heraion, placing it atop three immense bronze figures, seven cubits high, resting on their knees.

\footnotetext{
47 Tomlinson $(1992) 323$.

48 Strabo 17.808; see Athenaeus 13.596b and Herodotus 2.135.1, 5. See the discussion in Raaflaub's contribution to this volume.

49 In addition to the better-known Hellenion, in whose foundation the Mytileneans had participated, along with several Ionian cities.

5o See de Polignac (1997).

$5^{1}$ I thank Barbara Kowalzig for this suggestion. The colony is mentioned by Herodotus 4.90; see Asheri-Lloyd-Corcella (2007) 646.

$5^{2}$ I owe this reference to Pirenne-Delforge and Pironti (2014) 28 n. 17.
} 
Evidently, Herodotus' Kolaios knew whom he had to thank for his astonishing mercantile success, as the narrator suggests when he mentions the ship's 'divine accompaniment'. At least one expert believes that Kolaios may even have dedicated his entire ship to Hera. ${ }^{53}$ Two large ships were dedicated to her, along with Poseidon: at the Samian Heraion, on the processional route from the harbor to the temple, are two bases made of stone, dating from roughly 600 BCE, each of which supported a ship some thirty meters long. ${ }^{54}$

Helmut Kyrieleis, former director of excavations at the Heraion in Samos, also calls attention to some forty small (o.4 meters long) ship-shaped wooden objects that have been discovered there, which 'reproduce the elegant shape of Greek warships and trading vessels in simplified form. ${ }^{55}$ Given their rough workmanship he doubts that these were dedications: 'Their appearance ... might suggest that these boats played a role in the ritual of festivals of Hera as a kind of symbolic cult object'.

Kyrieleis draws a comparison with a contemporary Christian cult at Foce del Sele on the Campanian coast near Paestum, within the site of another [formerly] coastal Heraion: "There is a chapel in the sanctuary of Hera ... which is dedicated to the Madonna del Granato who, by virtue of her epithet and the attribute of a pomegranate, must be the Christian successor of ... Hera. Even now there is an annual festival in [her] honour ... in which little decorated ships of the simplest form are carried in procession, although nowadays the inhabitants have nothing to do with seafaring ...56 Kyrieleis further notes (p. 143) that in the Hera sanctuaries at Tiryns and Perachora, 'archaic terracotta figures ... show the goddess holding a little boat decked with flowers. These are, at the very least, strong indications that representations of ships functioned as a symbol or cult object in the ritual of Hera's festival'. François de Polignac, in a study of Hera sanctuaries that included archaic (eighth through sixth century) small models of boats or houses, mentions Samos and Perachora as find-spots of small wooden boat models; he compares the small bronze boats dedicated at the Heraion on Cape Lacinia near Croton, and that of Gravisca as well. ${ }^{57}$

Widespread throughout the Mediterranean in the seventh and sixth centuries (and beyond), then, are Greek settlements where Hera sanctuaries were

\footnotetext{
53 Walter (1990) 88-89.

54 Walter (1990) 82-88; de Polignac (1997) 116.

$55 \quad$ Kyrieleis (1993) 141-142; citation from p. 141.

$5^{6}$ Kyrieleis (1993) 142. The boat shapes form the bases of the so-called centi to which candles (nominally a hundred) are attached and carried in procession.

57 De Polignac (1997) 114-115. Models of boats have also been found at sanctuaries not identified as Heraia; see the map at de Polignac (1997) 114 for locations.
} 
located near harbors; some of these have yielded dedications that speak to her relationship with traders and other seafarers. To this list I would now add Messon (for which, unfortunately, there is a dearth of archaic dedications). With Hera's role as helper or hinderer of seafarers attested in the archaeological as well as the literary record, it is clear that the speaker in the Charaxos Poem proposes the appropriate local god to supplicate for Charaxos' safe voyage home-and the song itself may have been performed or reperformed in that god's maritime sanctuary.

\section{Hera and Zeus in the Charaxos Poem}

I conclude by comparing Hera's role in the new song with that of her partner Zeus. Like Hera, Zeus is rarely named in Sappho. He appears, as we have seen, in fr. 17 when the Atreid kings, seeking a way home, approach 'Zeus of Suppliants' (17.9) and 'Thyone's alluring son' (17.10) along with Hera, the god whose festival they vowed to celebrate, and whom alone the speaker addresses in this song (17.2-4). Apart from the Charaxos Poem, the name of Zeus is attested elsewhere in Sappho only at fr. 1.2, where Aphrodite is addressed inter alia as 'child of Zeus' ( $\pi \alpha \hat{\imath} \Delta$ ios), and at fr. 57 , where the Charites are 'daughters of Zeus' ( $\Delta$ ios xópal). ${ }^{58}$ Zeus is never addressed by the speaker in the corpus of Sappho; only in the Charaxos Poem does he act (and even then, as we shall see, in very general terms).

Zeus appears twice in that song. First, critical of the interlocutor's vain chatter about Charaxos and his ship, the speaker says piously but dismissively:

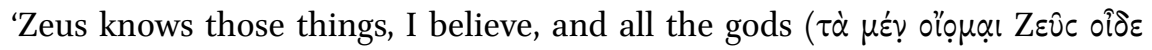

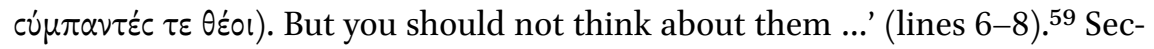
ond, she declares: 'Whomsoever the King of Olympos wishes a helpful daimon to turn away now from troubles, they become blessed and very fortunate' $(x \hat{\eta} v 01$

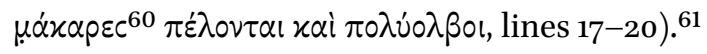

58 Obbink (2014b) 43 briefly contrasts Alcaeus' Zeus with Sappho's.

59 On this generalization see West (2014) 8 and Obbink (2014b) 43.

6o The term $\mu \alpha \dot{\alpha} x \alpha \rho \varepsilon c$ may have a special resonance on Lesbos, which is designated in Il. 24.544

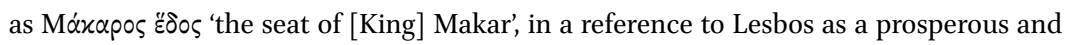
populous land. On early sources for Makar see Fowler (2013) 2.515-517.

61 I follow here the interpretation of Obbink (2014b) 44, further discussed by Lidov in this volume (ch. 3), rather than the lectio facilior that West (2014) 9 proposes in line 18

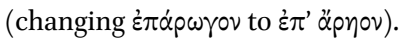


Both statements about Zeus in this song are broad generalizations. In the first instance, 'Zeus knows those things, I believe, and all the gods'62 concerns the gap between mortals and immortals. In saying this, the speaker implies that her interlocutor cannot really know about the return of Charaxos, and should not pretend to; she does not imply that Zeus will act on this knowledge. When Zeus reappears in the song, as one who can choose to turn away troubles, nothing is specified about the contents or recipients of his favor. Moreover, his blessing is granted not directly, but through an unspecified 'helpful daimon'. ${ }^{63}$ A welcome turn such as this happens spontaneously, when it happens, through the will of Zeus; it is not presented as the result of human supplication. Similarly general is the hopeful statement (lines 13-16) that immediately precedes

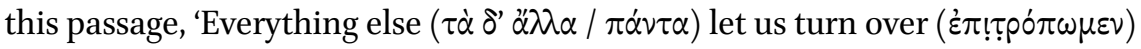
to the daimones, for from great gales clear skies quickly emerge'. ${ }^{64}$ Here too, no specific request is made of the superior powers; they operate on their own, as it were. ${ }^{65}$

Certainly, the speaker and her audience (and we!) may well think that Zeus could send a daimon to help Charaxos, the interlocutors, or even Larichosbut despite the apparently critical situation in the poem's 'here and now', no such connection is made. Zeus is not supplicated to help with Charaxos' safe homecoming, or with anything else. This is especially noteworthy because we know that as Antiaos 'god of suppliants' Zeus shared with Hera (and Dionysus) the pan-Lesbian sanctuary where the prayer for Charaxos was most likey to take place (lines 9-13).

62 West (2014) 8 provides parallel expressions in Il. 3.308; Od. 14.119, 15.523; Pind. fr. 94b.33. See also Parker (2011) $65^{-67}$ for an illuminating discussion of the difference between a single god and '[all] the gods' in Greek religious language.

63 Bierl (ch. 14), Lidov (ch. 3), and Obbink (ch. 9) in this volume suggest that the unnamed daimon refers to Dionysus. In my opinion, 'a helper daimon' is an unlikely way for the speaker to refer to a major deity, and in particular to the third member of the 'Lesbian triad'. Unlike in this context, Dionysus is referred to unmistakably both times the group is

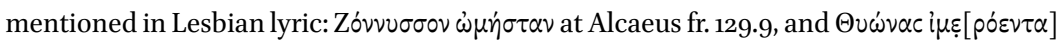
$\pi \alpha \hat{\delta} \delta \alpha$ at Sappho fr. 17.10. For an intriguing argument that the unnamed daimon may refer instead to the Dioscuri, see Kurke's contribution to this volume.

64 The weather metaphor is apt for the context of seafaring, but is also a commonplace. See West (2014) 8, who notes: 'The imagery recalls Solon (13.17-24) and Pindar (Pyth. 5.10, Isthm. 7.38), but the optimistic homely wisdom is characteristic of Sappho (cf. fr. 1.21-24 and $31.17\langle-20\rangle)$ '.

65 See Stehle's contribution to this volume for a thoughtful discussion of daimones as agents who cannot be supplicated. 
It is quite different with Hera. If the speaker's forceful instructions are followed, she will be sent to ply that goddess with prayers ( $\pi$ ó $\lambda \alpha \lambda$ ịccec $\theta \alpha$ l, line 10) to seek a defined result: bring Charaxos home with a safe ship and let him find us unharmed as well. Whereas the speaker generalizes about Zeus, 'all the gods', and the daimones, without making a request, here she uses emphatic, emotive language to describe how she should beg Hera for something specific. Lissomai, for which 'pray' is a pale translation, is a rare word in Lesbian lyric; its only other attestation in Sappho is in the (ironically) anguished prayer to Aphrodite ( $\lambda i \sigma-$ $\sigma \propto \mu \alpha i$ $\sigma \varepsilon$, fr. 1.2). ${ }^{66}$ Compared to the speaker's urgent errand and request, Zeus' power in this poem, while comprehensive, is remote and unspecific. ${ }^{67}$

For all these differences, Hera and Zeus balance each other in the Charaxos Song: specific vs. general, approachable vs. distant. Significantly, they also share the title $\beta \alpha \sigma i \lambda$ - 'sovereign' (another rare term in Lesbian lyric): ${ }^{68}$ Queen Hera (line 10) and King of Olympos (17). Zeus is often called 'O $\lambda u ́ \mu \pi$ ios in Greek epic, although never with the exact title $\beta \alpha c i \lambda \varepsilon v$ ' $^{\mathrm{O}} \mathrm{\lambda} \nu \mu \pi \omega / \mathrm{ov}$ (or metri gratia, 'O $\lambda \dot{\nu} \mu \pi \omega / 0 \cup \beta \alpha c i \lambda \varepsilon v c)$ 'king of Olympus', as here. In light of the contrast I draw between the divine pair in this song, the designation is very evocative, as it suggests his panhellenic rather than local identity. ${ }^{69}$ True, there is a Mount Olympus (a relatively common Aeolic place name) on Lesbos, some distance southeast of Messon, so there could be a local as well as a panhellenic valence in his title. ${ }^{70}$ The mountain is not attested in Lesbian poetry, however, and I know of no evidence of cult practiced there. Barring any attested cultic associations with the local place-name, I believe that the Homeric, panhellenic overtones of the phrase would resonate more with Sappho's audience.

66 The verb also occurs at Alcaeus fr. 374 (twice, perhaps in a Dionysiac context), and possibly at Alcaeus fr. 36.3. On the background of the root lit- see Benveniste (1969) 2.248-249, who argues that it means in origin (based on its use in Homeric epic) not simply to ask or supplicate, but to supplicate [a god] in atonement for an offense.

67 Ferrari (2014) 3-4 similarly notes the distinction between what Hera is asked to do and whatever else may happen. I am pleased to see that Kurke's conclusions (in this volume) about the relationship between Hera and Zeus in the Charaxos song, while based on rather different concerns and methodology, closely concur with my own reading.

68 Alcaeus refers to a $\tau \varepsilon \hat{i} \chi 0 \varsigma \beta \alpha \sigma \lambda \eta \eta$ í marginal note ad loc. explains this as 'the [wall] of Hera' (see Liberman [1999] 1.63). This phrase again connects the goddess at Messon with sovereignty.

69 Obbink (2014b) 44 remarks: 'In contrast to [line] 2, where Zeus is named, here Zeus' identity is paraphrased in terms of cosmic genealogy', and briefly discusses other instances of Olympios and Olympos in Sappho and Alcaeus. Cf. Obbink, ch. 9, this volume, pp. 213214 .

As suggested by Anton Bierl, per litteras. 
In a valuable study of Zeus and Hera on Lesbos, Vinciane Pirenne-Delforge and Gabriella Pironti also emphasize the special link between Zeus and Hera as basileis in the Brothers [or Charaxos] Poem. ${ }^{71}$ They compare the pair's relationship in a Mytilenean civic inscription dated to $33^{2}$ BCE (SEG $\left.36.75^{\circ}\right) .{ }^{72}$ This inscription concerns a vow by the Mytileneans to offer a sacrifice and procession if democracy and civic concord are re-established in their city, and names the gods to whom these honors are promised. Among these (Hera herself is not named) is 'Zeus Heraios and King and Concordant' ( $\tau \hat{\omega} \iota \Delta \iota \imath \tau \hat{\imath} \iota$

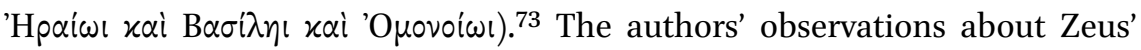
epithet Heraios are most interesting, particularly their acute argument that because Zeus' relationship with Hera is often portrayed as combative, it is significant that his close relationship to-even dependence on-his spouse is emphasized in a prayer for the restoration of civil concord. ${ }^{74}$ Pirenne-Delforge and Pironti argue that in the Brothers Poem as well as the inscription, 'the presence of Hera is decisive (déterminante): Zeus is described first of all as spouse of Hera. ${ }^{75}$

I concur that the two gods form a composite in the song, highlighted by their common epithet, but I find that the Charaxos Poem entails a different relationship between the pair from that in the inscription. The Hellenistic inscription is concerned with restoration of political concord in Mytilene, for which Zeus' close relationship to Hera is of utmost significance. Sappho's song, on the other hand, is formulated in terms of immediate personal (and probably familial) concerns; it brings to mind the maritime sanctuary with its 'pan-Lesbian triad', where Hera predominates (in Sappho and sometimes in Alcaeus) and is especially relevant in a prayer for a returning seafarer. The Charaxos Song distinguishes between Hera's immediate role on the one hand, and, on the other, Zeus' wide-ranging knowledge and unpredictable ability to change things for the better. (In these respects he is not clearly distinguished from the gods [theoi, line 7] or daimones [line 14] in general.) Overall, then, I find most striking the complementary differences in the roles Sappho assigns to the two gods; both are 'sovereign', but within very different parameters.

\footnotetext{
$71 \quad$ Pirenne-Delforge and Pironti (2014) 29.

72 Pirenne-Delforge and Pironti (2014) 30.

73 The full list is 'to the Twelve Gods, Zeus Heraios and King and Concordant, Concord

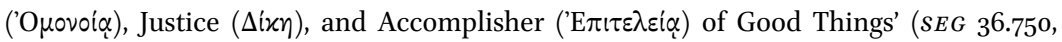
lines 6-8).

74 Pirenne-Delforge and Pironti (2014) 30-31.

75 Pirenne-Delforge and Pironti (2014) 30.
} 
Moreover, the help this local Hera is begged to provide for Charaxos' return may also have implications in the concluding hope for young Larichos, if-as Lidov (ch. 3), Obbink (ch. 9), and Stehle propose in this volume (and PirenneDelforge and Pironti in their article ${ }^{76}$ )—his 'becoming a man', and 'freeing us from the many cares weighing down our hearts', includes his maturation and marriage, which are special concerns of Hera's. That would indeed help keep 'us' 'safe and sound' ( $\alpha$ $\tau \varepsilon \dot{\mu} \mu \varepsilon \alpha c)$, with or without Charaxos' safe return.

To return the question with which I began this essay: why Hera in the Charaxos Poem? For Charaxos' safe return from sea and his reunion with those who await him safe at home, this local goddess, presiding in the shared sanctuary near the harbor at Messon, is decisively the dieu juste for Sappho's song.

76 See Pirenne-Delforge and Pironti (2014) 28-29, on Hera as $\pi \dot{\alpha} \nu \tau \omega \nu \gamma \varepsilon v \varepsilon \dot{\varepsilon} \theta \lambda \alpha \nu$ (Alc. fr. 129.6-7, discussed above), and likely concerned with the maturation of young men as well as girls on Lesbos. 